\title{
EFFECTS OF INLET TEMPERATURE AND CARRIER CONCENTRATION ON SPRAY-DRIED 'CEMPEDAK' (ARTOCARPUS INTEGER) FRUIT POWDER AND ITS RECONSTITUTION PROPERTIES
}

\author{
Liew Phing Pui ${ }^{\bowtie}$, Roselina Karim², Yus Aniza Yusof ${ }^{3}$, Chen Wai Wong ${ }^{4}$, \\ Hasanah Mohd. Ghazali ${ }^{5}$ \\ ${ }^{1}$ Department of Food Science, Faculty of Applied Sciences, UCSI University \\ 56000 Kuala Lumpur, Malaysia \\ 2Department of Food Technology, Faculty of Food Science and Technology, Universiti Putra Malaysia \\ 43400 Serdang, Selangor, Malaysia \\ ${ }^{3}$ Department of Process and Food Engineering, Faculty of Engineering, Universiti Putra Malaysia \\ 43400 Serdang, Selangor, Malaysia \\ ${ }^{4}$ Department of Biotechnology, Faculty of Applied Sciences, UCSI University \\ 56000 Kuala Lumpur, Malaysia \\ ${ }^{5}$ Department of Food Science, Faculty of Food Science and Technology, Universiti Putra Malaysia \\ 43400 Serdang, Selangor, Malaysia
}

\begin{abstract}
Background. 'Cempedak' (Artocarpus integer) is an aromatic fruit which is similar to jackfruit. Although it is rich in vitamin A and is consumed fresh, the fruit has a short shelf life. Hence, it can be converted through a spray-drying process, to form powder, which is more stable. Powder flow properties are important when considering storage, while its reconstitution characteristics are critical for the consumer to make juice from the product.

Materials and methods. The parameters of spray-dried 'cempedak' fruit powder under study include inlet air temperature $\left(140-180^{\circ} \mathrm{C}\right)$ and maltodextrin (DE 10) concentrations $(5-15 \% \mathrm{w} / \mathrm{w})$. Response surface methodology involving 14 runs was used to assess the effects of inlet temperature and maltodextrin on the powder flow properties and reconstitution properties of the spray-dried 'cempedak' powder.

Results. Out of the tested responses, only bulk density, change in cake height ratio, and water solubility index had a high coefficient of determination value. Inlet air temperature was found to be the main parameter to affect the bulk density, caking and water solubility index, when compared to maltodextrin concentration. By setting minimization of caking and maximization of water solubility index as the main determinants, the optimal parameters of $160^{\circ} \mathrm{C}$ inlet temperature and $15 \%(\mathrm{w} / \mathrm{w})$ maltodextrin DE10 were generated, with a desirability of 0.697 .

Conclusion. The powder produced under optimal conditions $\left(160^{\circ} \mathrm{C}\right.$ and $15 \% \mathrm{w} / \mathrm{w}$ maltodextrin) had a low bulk density $\left(480.01 \mathrm{~kg} / \mathrm{m}^{3}\right)$, low caking properties ( 0.17 change in cake height ratio), and a high solubility index (88.69). This indicates that the powder is stable to be stored (without caking) and will have good reconstitution when added to water.
\end{abstract}

Keywords: ‘cempedak' powder, spray-drying, inlet temperature, maltodextrin, powder flow, reconstitution

This study was supported by the Universiti Putra Malaysia, Malaysia, under Project no. GP IPS/2013/9399839.

『puilp@ucsiuniversity.edu.my, https://orcid.org/0000-0001-5305-4334 


\section{INTRODUCTION}

'Cempedak', with the scientific name of Artocarpus integer, is a yellow fruit similar to the jackfruit, and with an attractive aroma (Subhadrabandhu, 2001). The flesh of ripe 'cempedak' can either be consumed fresh or deep fried into fritters, dried into chips or creamed to make cakes (Lim et al., 2011), while the unripe 'cempedak' is cooked as a soup dish (Janick and Paull, 2008). The Recommended Dietary Allowance (RDA) for vitamin $A$ is $0.6-0.9 \mathrm{mg} /$ day, which translates to approximately 7 to $10.8 \mathrm{mg}$ of b-carotene. In $\mathrm{CH} 28$ 'cempedak', there is $45.27 \mu \mathrm{g} / 100 \mathrm{~g} \mathrm{FW} \alpha$-carotene and $12.23 \mu \mathrm{g} / 100 \mathrm{~g} \mathrm{FW} \beta$-carotene, respectively (Pui et al., 2018). 'Cempedak' is a seasonal fruit which is not available all year round. Hence, 'cempedak' fruit powder can be produced to preserve the shelf life of the 'cempedak' product.

Drying helps to reduce the moisture content of the product, which then allows safe storage over an extended period (Doymaz and Kocayigit, 2011). The spray-drying method is widely utilized in the production of fruit powder (Phisut, 2012). Although there are a few factors that need to be considered during spray-drying, the inlet temperatures and carrier concentration are the parameters that are optimized most. Spray-dried fruit juice powders have a high content of sugar solids, causing the powder to be prone to caking during storage (Bhandari et al., 1997). The addition of maltodextrin (MD) is commonly used in the production of fruit powders, where it functions as a wall material to envelope spray-drying feed and improve powder yield (Bhandari et al., 1997; Chew et al., 2019; Quek et al., 2007; Yousefi et al., 2011). It is also used in the production of fruit powders such as tamarind, sumac, Sarawak pineapple, Solanum lasiocarpum and papaya (Bhusari et al., 2014; Caliskan and Dirim, 2013; Chang et al., 2020a; Chang et al., 2020b; Wong et al., 2015).

In the food industry, the characterization of flow properties is essential as it can prevent production stoppages (Benković et al., 2013). Powder flow properties can be measured using a powder rheometer, which provides a quick and easy measurement of powder cohesivity (Benković et al., 2013; Freeman, 2007). Bulk density is the weight of dried powder per unit volume. It is critical for spray-drying operations because it determines the size of containers and affects the handling and shipping cost of transportation (Grandison and Lewis, 1996).

Reconstitution of food powders is of particular importance both to manufacturers and to consumers, being one of the critical benchmarks of the quality of food powder for consumption (Chen and Patel, 2008). The instant properties of a powder include the ability of a powder to dissolve in water (Grabowski et al., 2006). Reconstitution or dissolution of food powder generally consists of four steps or phases: wetting of the powder particles, sinking, dispersing and the particles completely dissolving in the solution (Fang et al., 2007). On the other hand, the solubility index serves to determine the behavior of the powder in its aqueous phase (Chen and Patel, 2008). Product color is another important quality attribute for fruit powders as it serves as the primary consumer-recognized aspect of food acceptance. Color can be influenced by spray-drying temperatures and feed additives, along with other factors during spray-drying (Abadio et al., 2004).

Therefore, this research aims to investigate the effects of spray-dryer inlet air temperature and maltodextrin concentration on 'cempedak' fruit powder properties, in relation to powder flow and reconstitution. Powder properties such as density, powder flow, particle size and surface morphology were also examined. The 'cempedak' fruit powder produced was reconstituted and further subjected to tests, which included water solubility index (WSI), color and viscosity.

\section{MATERIALS AND METHODS}

\section{Materials}

The 'Cempedak' (Artocarpus integer L.) variant used in this study, $\mathrm{CH} 28$, was purchased from the Department of Agriculture, Serdang, Selangor, Malaysia. Maltodextrin $10 \mathrm{DE}$ and Celluclast ${ }^{\circledR} 1.5 \mathrm{~L}$ were supplied by Bronson and Jacobs Ptd. Ltd. (Kuala Lumpur, Malaysia) and Novozymes, Denmark, respectively.

\section{Preparation of spray drying feed}

The pulp of the 'cempedak' fruit was obtained by cutting the fruit in half and separating the fruit bulbs from the seed. It was then vacuum packed in transparent 

spray-dried 'cempedak' (Artocarpus integer) fruit powder and its reconstitution properties. Acta Sci. Pol. Technol. Aliment., 20(2), 135-148. http://dx.doi.org/10.17306/J.AFS.2021.0801

polyethylene plastic bags (estimated $200 \mathrm{~g}$ of pulp per packet) before being stored in the dark at $-20^{\circ} \mathrm{C}$. The 'cempedak' pulp was thawed at room temperature before the experiments. The pulp was cut into smaller pieces and homogenized at low speed using a commercial blender into puree form. The homogenized 'cempedak' puree was mixed with distilled water at 1:2 puree: water ratio and incubated with $1.2 \%(\mathrm{v} / \mathrm{w})$ Celluclast $^{\circledR} 1.5 \mathrm{~L}$ for 1 hour at $45^{\circ} \mathrm{C}$ and $100 \mathrm{rpm}$ in a shaking water bath (WNB 14, Memmert GmbH \& Co. KG., Schwabach, Germany). It was then subjected to pasteurization $\left(5 \mathrm{~min}, 90^{\circ} \mathrm{C}\right)$ in a water bath (WNB 14, Memmert GmbH \& Co. KG., Schwabach, Germany).

The 'cempedak' puree treated with enzyme was filtered and added to maltodextrin DE 10 (2.9-17.1\% $\mathrm{w} / \mathrm{w}$ ) to serve as a spray-dryer feed. The total soluble solids of the feed before spray-drying was $10 \%$ wet weight. The mixture was homogenized (T25 basic lab homogenizer, IKA-Werke Gmbh \& Co., Staufen, Germany) at $9500 \mathrm{rpm}$ (Bakar et al., 2013).

\section{Spray-drying process}

The maltodextrin-containing feed was spray-dried using a Büchi B-290 mini spray-dryer equipped with the two-fluid nozzles and compressed air (Büchi Labortechnik AG, Flawil, Switzerland). The dryer was set at a flow rate of $900 \mathrm{~m}^{3} / \mathrm{min}$ air, a dryer aspirator rate of $100 \%$, and a pump rate of $10 \%$. The outlet air temperatures used ranged from $85-95^{\circ} \mathrm{C}$, with a feed flow rate of $5 \mathrm{~mL} / \mathrm{min}$. Spray-drying was carried out according to the parameters in Table 1, as generated from the response surface methodology (RSM). Spray-dried 'cempedak' fruit powders were collected from the product vessel.

\section{Analysis of spray-dried 'cempedak' powder}

Density and porosity. The determination of the bulk density of 'cempedak' powder was carried out in accordance with Caliskan and Dirim (2013), where the powder $(5 \mathrm{~g})$ was placed into a $20 \mathrm{~mL}$ graduated measuring cylinder, where the volume was taken and the bulk density calculated as below:

Bulk density $\left(\rho\right.$ Bulk), $\mathrm{kg} / \mathrm{m}^{3}=\frac{\text { powder mass }}{\text { volume of powder }}$
Table 1. Experimental conditions for optimizing the spray-drying of enzyme-treated 'cempedak' juice using response surface methodology

\begin{tabular}{rrrlc}
\hline Standard & Run & Block & $\begin{array}{c}\text { Inlet air } \\
\text { temperature } \\
\left(x_{1}\right) \\
{ }^{\circ} \mathrm{C}\end{array}$ & $\begin{array}{c}\text { Maltodextrin } \\
\text { concentration } \\
\left(x_{2}\right) \\
\% \mathrm{w} / \mathrm{w}\end{array}$ \\
\hline 2 & 1 & 1 & $180(+1)$ & $5.0(-1)$ \\
3 & 2 & 1 & $140(-1)$ & $15.0(+1)$ \\
6 & 3 & 1 & $160(0)$ & $10.0(0)$ \\
4 & 4 & 1 & $180(+1)$ & $15.0(+1)$ \\
5 & 5 & 1 & $160(0)$ & $10.0(0)$ \\
1 & 6 & 1 & $140(-1)$ & $5.0(-1)$ \\
7 & 7 & 1 & $160(0)$ & $10.0(0)$ \\
10 & 8 & 2 & $160(0)$ & $2.9(-1.41)$ \\
8 & 9 & 2 & $132(-1.41)$ & $10.0(0)$ \\
12 & 10 & 2 & $160(0)$ & $10.0(0)$ \\
11 & 11 & 2 & $160(0)$ & $17.1(+1.41)$ \\
14 & 12 & 2 & $160(0)$ & $10.0(0)$ \\
9 & 13 & 2 & $188(+1.41)$ & $10.0(0)$ \\
13 & 14 & 2 & $160(0)$ & $10.0(0)$ \\
\hline & & & &
\end{tabular}

In measuring the tapped density ( $\rho$ Tapped) of 'cempedak' fruit powders, the cylinder was tapped 120 times, and the volume of the powder was taken (Caliskan and Dirim, 2016).

Tap density $(\rho$ Tapped $)=\frac{\text { mass of powder }}{\text { final tapped volume }}$

The true density of the 'cempedak' fruit powder was determined by employing a gas pycnometer (AccuPyc II 1340, Micromeritics, Norcross, Georgia, USA) according to the method described by $\mathrm{Ng}$ et al. (2012). The 'cempedak' fruit powder (approximately $0.5 \mathrm{~g})$ was placed in the sample chamber $\left(1 \mathrm{~cm}^{3}\right)$ and the weight recorded. The sample was then placed in a sealed compartment where helium gas released. The gas displacement density was then measured.

The porosity of the 'cempedak' fruit powder was calculated following equation 3 below (Bhusari et al., 2014). 


$$
\text { Porosity, } \%=100-\frac{\text { bulk density }}{\text { true density }}
$$

Hausner Ratio and Carr's Index. Cohesiveness was determined using the Hausner Ratio (HR), while the flowability of the 'cempedak' fruit powder was measured using the Carr's Index (CI) (Caliskan and Dirim, 2016). Both HR and CI were calculated using equations 4 and 5 shown below.

$$
\begin{gathered}
\text { Hausner Ratio }(\mathrm{HR})=\frac{\rho \text { Tapped }}{\rho \text { Bulk }} \\
\text { Carr's Index }(\mathrm{CI})=100 \times \frac{\rho \text { Tapped }-\rho \text { Bulk }}{\rho \text { Tapped }}
\end{gathered}
$$

where:

$\rho$ Tapped - the tapped density,

$\rho$ Bulk - the bulk density.

The HR defines the powder cohesiveness, while the Carr's Index indicates the degree of powder flowability.

Flow properties of 'cempedak' fruit powder. The flow properties of 'cempedak' fruit powder were determined using a powder rheometer, TA.HD Plus Texture Analyzer equipped with Exponent 32 Software (Stable Micro Systems, Godalming, UK). The caking test, cohesion test and powder flow speed dependency test (PFSD) were performed according to the method by Janjatović et al. (2012).

To determine the caking properties, the test began with two conditioning cycles after the 'cempedak' powder was poured into the column, where the blade moved to the top of powder column to measure its height, followed by moving down through the height of the column and then moved up and down again at $20 \mathrm{~mm} / \mathrm{s}$, to compact the powder to $200 \mathrm{~g}$ force. The blade then sliced through the powder at $10 \mathrm{~mm} / \mathrm{s}$ 5 times. During the fifth time, the measurement of the force required was recorded as the cake strength $(\mathrm{g} \cdot \mathrm{mm})$. The change in cake height ratio (cake height/ initial column height) was recorded.

The cohesion properties of the 'cempedak' fruit powder started with a fixed sample volume $(40 \mathrm{~mL})$ weighed and poured into the powder column. The rotating blade moved downwards and, after two cycles, the cohesion property was recorded, while the cohesion index was calculated. Based on the cohesion index, the powders can be categorized with values less than 11 considered to be free flowing, 11-14 easy flowing, 14-16 cohesive, 16-19 very cohesive and values of more than 19 hardened and extremely cohesive (Benković and Bauman, 2009).

The powder flow speed dependency (PFSD), on the other hand, started with two conditioning cycles before a cycles were run at $10 \mathrm{~mm} / \mathrm{s}, 20 \mathrm{~mm} / \mathrm{s}, 50 \mathrm{~mm} / \mathrm{s}$, $100 \mathrm{~mm} / \mathrm{s}$ and two final cycles at $10 \mathrm{~mm} / \mathrm{s}$. The flow stability index was then calculated.

Particle size. The particle size distribution of the 'cempedak' fruit powder was determined using a laser light diffraction instrument (Mastersizer 2000, model Hydro 2000MU, Malvern Instruments, Malvern, UK). The particle size distribution was monitored using the properties parameter (D 0.5).

Surface morphology. The surface morphology of the 'cempedak' fruit powder was determined using a scanning electron microscopy (SEM) (Leo 1455 Variable Pressure SEM, Carl Zeiss, Germany). The 'cempedak' fruit powders were attached using a two-sided carbonconducting tape and coated with gold (sputter coater, Bal-tec SCD 005, Japan) under vacuum (Tonon et al., 2008). Scanning electron micrographs were obtained $(5 \mathrm{kV}$, digital images of $2000 \times$ magnifications).

\section{Water solubility index (WSI) of spray-dried 'cem-} pedak' fruit powder. The water solubility index (WSI) of the spray-dried 'cempedak' fruit powder was evaluated using the method by Grabowski et al. (2006) with slight modifications. The 'cempedak' powder $(1 \mathrm{~g})$ was added to $10 \mathrm{~mL}$ of water and mixed vigorously using a vortex for $30 \mathrm{~s}$ in a $15 \mathrm{~mL}$ centrifuge tube.

Subsequently, the powder suspension was subjected to incubation $\left(37^{\circ} \mathrm{C}, 30 \mathrm{~min}\right)$ followed by centrifugation (Beckman J2-21M/E, Beckman Coulter, Inc., California, USA) at $3000 \mathrm{rpm}$ for $10 \mathrm{~min}$ at room temperature. The supernatant was collected, placed in a small aluminum tray and dried overnight in an oven (UFB 500, Memmert GmbH \& Co. KG, Schwabach, Germany) at $105^{\circ} \mathrm{C}$. The dried material was then weighed, and WSI was expressed as the percentage of the total dry solids over the original weight of 'cempedak' fruit powder used in the analysis. 

below.

The calculation of WSI was shown in the equation

WSI $=\frac{\text { weight of residue }}{\text { weight of 'cempedak' fruit powder }} \times 100 \%$

Reconstitution of 'cempedak' fruit powder. To reconstitute the 'cempedak' fruit back to the same solids content as the filtered 'cempedak' juice (filtered enzyme-liquefied puree; $10 \%)$, the powder $(2.5 \mathrm{~g})$ was mixed with $25 \mathrm{~g}$ of water and vortexed at the highest speed for 2 min (Grabowski et al., 2008).

Color of reconstituted powder. The color of the reconstituted 'cempedak' fruit powder was evaluated using a Hunter Lab Ultra-Scan ColorFlez Colorimeter (Hunter Associate Laboratory Inc., Reston, USA). The total color change $(\Delta E)$ was calculated according to equation 8 (Pua et al., 2008).

$$
\Delta E=\sqrt{(L-L o)^{2}}+(a-a o)^{2}+(b-b o)^{2}
$$

The viscosity of reconstituted powder. The viscosity of the reconstituted 'cempedak' fruit powder was measured using a Brookfield viscometer (DV-II + Pro, Brookfield Viscometer Ltd., Harlow, UK) equipped with RheocalcT 3 software, with a small sample adaptor spindle (SSA). Approximately $15 \mathrm{~mL}$ of the reconstituted powder was required to fill the sample cup. The spindle was then lowered to the sample cup to start the analysis at $20 \mathrm{rpm}$ rotational speed. The viscosity reading was recorded 3 times in 1 minute via Rheocalc software once the analysis had started, and the viscosity value expressed in centipoise, $\mathrm{cP}$.

\section{Experimental design and statistical analysis}

Design Expert 10 software (Stat-Ease, USA) was applied to conduct a response surface analysis where two factors: inlet air temperature ranging from $140-180^{\circ} \mathrm{C}$ and maltodextrin concentration from $5.0-15.0 \%$ were optimized. With the central composite design of response surface methodology, there are \pm 1.41 as additional points, together with central points and two axial points, giving a total of $14 \mathrm{com}-$ binations (Table 1). In addition, the design is conducted in 2 blocks, due to experiments performed on different days.
The data obtained was expressed using the polynomial equation (8) (Bakar et al., 2013).

$$
y=b_{0}+b_{1} x_{1}+b_{2} x_{2}+b_{11} x_{1}^{2}+b_{22} x_{2}^{2}+b_{12} x_{1} x_{2}
$$

where

$b_{0} \quad$ - constant,

$b_{1}, b_{2}$ - linear coefficients,

$b_{12} \quad$ - cross-product coefficients,

$b_{11}, b_{22}$ - quadratic coefficients.

Design Expert 10 software was then applied to determine the analysis of variance (ANOVA), test for the lack of fit, determine the regression coefficients and generate the contour plot for significant variables in each response. In order to determine the optimal inlet temperatures and maltodextrin, the criteria for desirable responses was set to be maximized or minimized at different importance levels. From the optimal point generated through the software, the experiments were carried out to validate the optimized value.

\section{RESULTS AND DISCUSSION}

Table 2 describes the experimental responses of spraydried 'cempedak' fruit powder, while Table 3 portrays the regression model for the powder flow properties and solubility of spray-dried 'cempedak' fruit powder. Table 4, on the other hand, shows the estimated regression coefficients, corresponding determination coefficients $\left(R^{2}\right), R^{2}$ (adj.), $F$-value and $p$-value of lack of fit. The $R^{2}$ values obtained ( $\left.>0.8\right)$ for the response variables that are significant indicate that the response surface models were able to explain the response variations (de Oliveira et al., 2009). For this study, the responses that are of low $R^{2}$ (adj.) values were excluded from the optimization process (change in color of reconstituted powder $R^{2}$ adj. $=0.45$ ).

The regression models are considered to be accurate in describing the variation of the responses, supported by the lack of fit (Table 3). Generally, the linear effect of inlet air temperature and maltodextrin was significant for all responses (Table 4). The quadratic effects of inlet air temperature and maltodextrin concentration were found to be nonsignificant $(p>0.05)$ for all response regressions except for the water solubility index, while the interaction effects of inlet air temperature and maltodextrin concentration were significant $(p \leq 0.05)$ for changes in cake height ratio (Table 4). 
Pui, L. P., Karim, R., Yusof, Y. A., Wong, Ch. W., Ghazali, H. M. (2021). Effects of inlet temperature and carrier concentration on spray-dried 'cempedak' (Artocarpus integer) fruit powder and its reconstitution properties. Acta Sci. Pol. Technol. Aliment., 20(2), 135-148. http://dx.doi.org/10.17306/J.AFS.2021.0801

Table 2a. Experimental responses of spray-dried ‘cempedak' fruit powder

\begin{tabular}{|c|c|c|c|c|c|c|c|c|}
\hline Run & $\begin{array}{c}\text { Bulk density } \\
\qquad\left(\mathrm{Y}_{1}\right) \\
\mathrm{kg} / \mathrm{m}^{3}\end{array}$ & $\begin{array}{l}\text { Porosity } \\
\left(\mathrm{Y}_{2}\right)\end{array}$ & $\begin{array}{l}\text { Hausner ratio } \\
\left(\mathrm{Y}_{3}\right)\end{array}$ & $\begin{array}{c}\text { Carr's index } \\
\left(\mathrm{Y}_{4}\right) \\
\%\end{array}$ & $\begin{array}{c}\text { Change in cake } \\
\text { height ratio } \\
\left(\mathrm{Y}_{5}\right)\end{array}$ & $\begin{array}{c}\text { Cohesion index } \\
\left(\mathrm{Y}_{6}\right) \\
\mathrm{mm}\end{array}$ & $\begin{array}{l}\text { Flow stabil- } \\
\text { ity index } \\
\left(\mathrm{Y}_{7}\right)\end{array}$ & $\begin{array}{c}\text { Particle size } \\
\left(\mathrm{Y}_{8}\right) \\
\mu \mathrm{m}\end{array}$ \\
\hline 1 & 486 & 0.71 & 1.67 & 40.29 & 0.01 & 10.6 & 0.89 & 266.24 \\
\hline 2 & 441 & 0.72 & 1.89 & 47.09 & 0.26 & 11.1 & 0.86 & 183.77 \\
\hline 3 & 481 & 0.73 & 1.53 & 34.74 & 0.23 & 10.6 & 0.94 & 118.10 \\
\hline 4 & 387 & 0.72 & 1.80 & 44.37 & 0.13 & 12.1 & 0.94 & 162.19 \\
\hline 5 & 457 & 0.71 & 1.78 & 43.94 & 0.17 & 11.4 & 0.93 & 268.72 \\
\hline 6 & 530 & 0.70 & 1.58 & 36.67 & 0.42 & 11.1 & 0.95 & 246.62 \\
\hline 7 & 481 & 0.68 & 1.47 & 32.13 & 0.24 & 11.4 & 0.97 & 218.38 \\
\hline 8 & 500 & 0.65 & 1.45 & 31.19 & 0.28 & 12.3 & 1.07 & 198.44 \\
\hline 9 & 510 & 0.76 & 1.47 & 32.09 & 0.34 & 12.9 & 0.97 & 183.93 \\
\hline 10 & 446 & 0.66 & 1.58 & 36.62 & 0.15 & 12.2 & 0.94 & 198.03 \\
\hline 11 & 397 & 0.74 & 1.82 & 45.15 & 0.01 & 12.3 & 0.94 & 162.73 \\
\hline 12 & 446 & 0.66 & 1.50 & 33.26 & 0.17 & 12.2 & 0.95 & 191.76 \\
\hline 13 & 447 & 0.67 & 1.35 & 25.70 & 0.01 & 12.2 & 0.88 & 204.60 \\
\hline 14 & 490 & 0.65 & 1.52 & 34.31 & 0.20 & 10.1 & 0.95 & 211.14 \\
\hline
\end{tabular}

Table 2b. Experimental responses of solubility of spray-dried 'cempedak' fruit powder and properties of reconstituted 'cempedak' fruit powder

\begin{tabular}{rccc}
\hline Run & $\begin{array}{c}\text { Water solubility index } \\
\left(\mathrm{Y}_{9}\right)\end{array}$ & $\begin{array}{c}\text { Total color difference between lique- } \\
\text { fied juice and reconstituted powder }-\end{array}$ & $\begin{array}{c}\text { Viscosity reconstituted powder } \\
\left(\mathrm{Y}_{11}\right) \\
\mathrm{cP}\end{array}$ \\
\hline 1 & 83.05 & 5.79 & 4.58 \\
2 & 82.08 & 3.17 & 3.90 \\
3 & 87.18 & 3.09 & 4.11 \\
4 & 90.21 & 3.30 & 5.64 \\
5 & 86.63 & 3.80 & 5.30 \\
6 & 74.02 & 4.18 & 4.24 \\
7 & 85.46 & 3.32 & 3.55 \\
8 & 81.45 & 2.90 & 4.23 \\
9 & 81.38 & 4.01 & 4.50 \\
10 & 88.10 & 3.42 & 4.80 \\
11 & 89.17 & 2.68 & 3.85 \\
12 & 86.10 & 3.53 & 4.92 \\
13 & 89.36 & 7.00 & 5.67 \\
14 & 86.34 & 3.38 & 3.80 \\
\hline
\end{tabular}


Table 3. Regression model for powder flow properties and solubility of spray-dried 'cempedak' fruit powder

\begin{tabular}{lccc}
\hline $\begin{array}{l}\text { Regression } \\
\text { coefficient }\end{array}$ & $\begin{array}{c}\text { Bulk } \\
\text { density } \\
\left(\mathrm{Y}_{1}\right) \\
\mathrm{kg} / \mathrm{m}^{3}\end{array}$ & $\begin{array}{c}\text { Change in } \\
\text { cake height } \\
\text { ratio } \\
\left(\mathrm{Y}_{5}\right)\end{array}$ & $\begin{array}{c}\text { Water } \\
\text { solubility } \\
\text { index } \\
\left(\mathrm{Y}_{9}\right)\end{array}$ \\
\hline$b_{0}$ & 464.28 & 0.19 & 86.84 \\
$b_{1}$ & -23.38 & -0.13 & 3.56 \\
$b_{2}$ & -41.87 & -0.052 & 3.27 \\
$b_{1}{ }^{2}$ & - & - & -1.38 \\
$b_{2}{ }^{2}$ & - & - & -1.41 \\
$b_{12}$ & - & 0.068 & -0.22 \\
$R^{2}$ & 0.86 & 0.86 & 0.93 \\
$R^{2}$ (adj.) & 0.83 & 0.85 & 0.88 \\
Regression $p$-value & $<0.0001$ & 0.0001 & 0.0007 \\
Linear & $<0.0001$ & 0.004 & 0.0002 \\
Square & 0.2595 & 0.7990 & 0.0331 \\
Interaction & 0.7939 & 0.0224 & 0.8415 \\
Lack of fit $F$-value & 0.56 & 2.78 & 4.18 \\
Lack of fit $p$-value & 0.7486 & 0.1715 & 0.1003 \\
\hline
\end{tabular}

$b_{0}-$ constant term, $b_{1}-$ linear coefficient of inlet air temperature, $b_{2}$ - linear coefficient of maltodextrin concentration, $b_{1}^{2}-$ quadratic coefficient of inlet air temperature, $b_{2}{ }^{2}$ - quadratic temperature of maltodextrin concentration, $b_{12}$ - interaction effect of inlet air temperature (maltodextrin).

\section{Influence of independent variables on density and porosity of spray-dried 'cempedak' fruit powder}

The bulk density $\left(\mathrm{Y}_{1}\right)$ of the 'cempedak' fruit powder ranged from 397 to $530 \mathrm{~kg} \mathrm{~m}^{-3}$ (Table 2). Both the linear effects of inlet air temperature and maltodextrin concentration significantly $(p \leq 0.05)$ affected the bulk density of the 'cempedak' fruit powder. The effects of inlet air temperature and maltodextrin concentration on the bulk density of the spray-dried 'cempedak' fruit powder are illustrated in Figure 1.

Inlet air temperature correlated negatively with the bulk density of spray-dried 'cempedak' fruit powder, indicated that the powder can be packed in a smaller volume, thus it reduced the cost of transportation (Caliskan and Dirim, 2013). An increase in the inlet air temperature often resulted in a rapid formation of a dried layer on the droplet surface. This, in turn, causes the skinning over or casehardening of the droplets. Maltodextrin concentration had a more significant effect, negatively affecting the bulk density of the 'cempedak' fruit powder compared to inlet temperature (Table 4). The addition of maltodextrin lead to an increased volume of air trapped in the particles (Goula and Adamopoulos, 2008), thus increasing the bulk density of the powder and the space needed for packing (Caliskan and Dirim, 2013). On the other hand, inlet air temperature and maltodextrin concentration also do not have a significant effect $(p>0.05)$ on the porosity $\left(\mathrm{Y}_{2}\right)$ of spray-dried 'cempedak' fruit powder.

Table 4. The significance probability ( $p$-value and $F$-ratio) of regression coefficients in the polynomial response surface models

\begin{tabular}{lcccccc}
\hline \multicolumn{2}{c}{ Independent variables } & \multicolumn{2}{c}{ Linear effects } & \multicolumn{2}{c}{ Quadratic effects } & $\begin{array}{c}\text { Interaction } \\
\text { effects }\end{array}$ \\
\cline { 3 - 7 } & & $x_{1}$ & $x_{2}$ & $x_{1}^{2}$ & $x_{2}^{2}$ & $x_{12}$ \\
\hline Bulk density $\left(\mathrm{Y}_{1}\right), \mathrm{kg} / \mathrm{m}^{3}$ & $p$-value & 0.0036 & $<0.0001$ & - & - & - \\
Change in cake height ratio $\left(\mathrm{Y}_{5}\right)$ & $p$-value & $<0.0001$ & 0.0159 & 0.224 & - & - \\
Water solubility index $\left(\mathrm{Y}_{9}\right)$ & $p$-value & 0.0003 & 0.005 & 0.0431 & 0.0398 & 0.7763 \\
\hline
\end{tabular}

$x_{1}, x_{2}-$ the linear effect of inlet air temperature, ${ }^{\circ} \mathrm{C}$, and maltodextrin concentration, $\% \mathrm{w} / \mathrm{w}$, respectively.

$x_{1}^{2}, x_{2}^{2}$ - the quadratic effect of inlet air temperature, ${ }^{\circ} \mathrm{C}$, and maltodextrin concentration, $\% \mathrm{w} / \mathrm{w}$, respectively.

$x_{12}$ - the interaction effect of inlet air temperature, ${ }^{\circ} \mathrm{C}$, and maltodextrin concentration, $\% \mathrm{w} / \mathrm{w}$. 


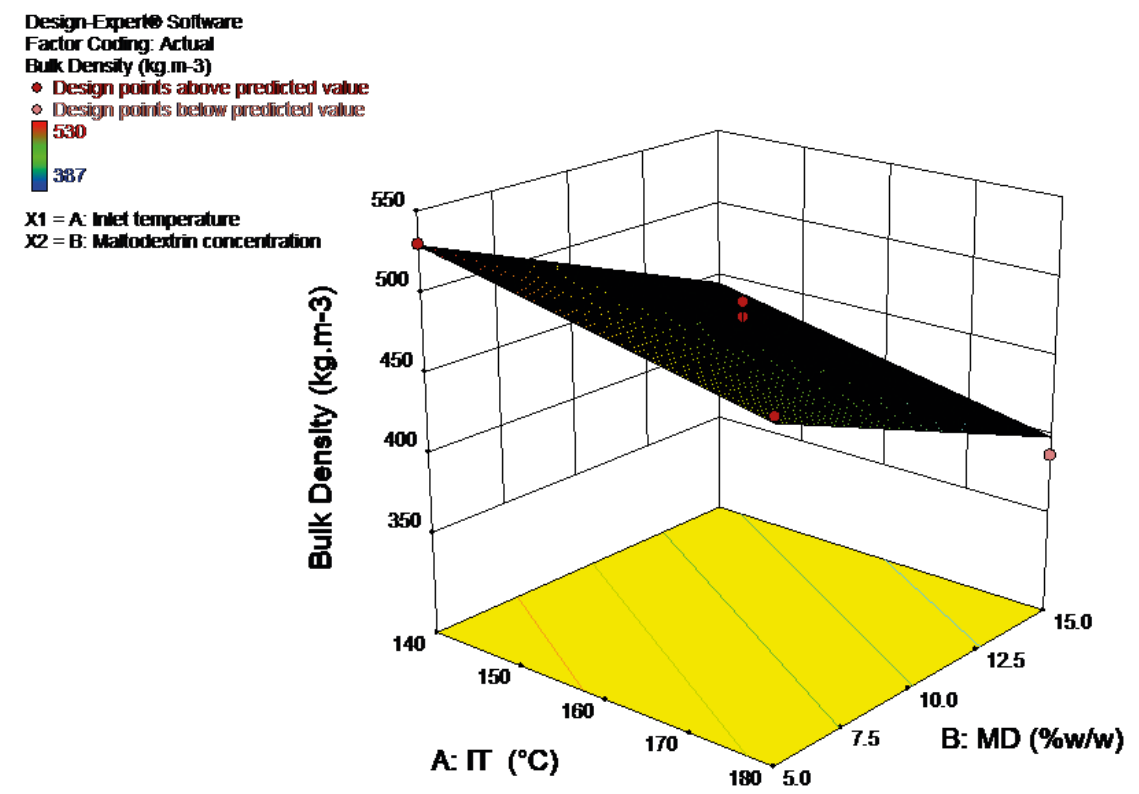

Fig. 1. Response surface plot for effects of inlet air temperature and maltodextrin concentration on the bulk density ( $\left.\mathrm{Y}_{1}\right)$ of spray-dried 'cempedak' fruit powder, $\mathrm{kg} / \mathrm{m}^{3}$ : IT - inlet air temperature, MD - maltodextrin concentration

\section{Influence of independent variables on powder flow, caking and cohesion of spray-dried 'cempedak' fruit powder}

From Table 3, it can be seen that inlet air temperature and maltodextrin concentration do not have a significant effect on the Carr's Index $\left(\mathrm{Y}_{3}\right)$ or Hausner Ratio $\left(\mathrm{Y}_{4}\right)$ of 'cempedak' fruit powder, ranging from 1.351.89 and 25.70-47.09, respectively. These results indicate that the 'cempedak' fruit powder has a high cohesiveness (high Carr's Index), while the powder flowability ranges from fair to very bad flow (high Hausner Ratio).

Caking occurs when the food powder, which is in an amorphous condition, transitions into a sticky material under conditions that result in a powder that loses its functionality and has a lower quality (Aguilera et al., 1995; Benković et al., 2013). Caking strength can be used to evaluate the potential of different samples to form a cake. It is defined as the forces required to cut through the cake formed (Shah et al., 2008).

As shown in Tables 3 and 4, the linear effects of inlet air temperature and maltodextrin concentration, and the quadratic effects of inlet air temperature have a significant effect $(p \leq 0.05)$ on change in cake height ratio $\left(\mathrm{Y}_{9}\right)$. The effects of inlet air temperature and maltodextrin concentration on change in cake height ratio are shown in Figure 2. Inlet air temperature has a high negative correlation with the change in the cake height ratio of 'cempedak' fruit powder (Table 3). A decreasing change in the cake height ratio indicates that it is less susceptible to caking (Janjatović et al., 2012). The lower moisture content at higher maltodextrin concentrations can also be the main reason which affects the change in cake height ratio between the first and the last caking cycle. Maltodextrin concentration also has a negative effect on the change in the cake height ratio of 'cempedak' fruit powder (Table 3 ). This decrease in powder caking as the maltodextrin increases is attributed to an increase in the glass transition temperature $\left(T_{g}\right)$ with the addition of maltodextrin (Shavakhi et al., 2012).

Powders can be classified into non-cohesive and cohesive, being referred to as powder flowability (Janjatović et al., 2012). The effects of both inlet air temperature and maltodextrin concentration on 'cempedak' fruit powder's cohesion index $\left(\mathrm{Y}_{6}\right)$, and flow stability $\left(\mathrm{Y}_{7}\right)$ of spray-dried 'cempedak' fruit powder were nonsignificant $(p>0.05)$. The cohesion index of 


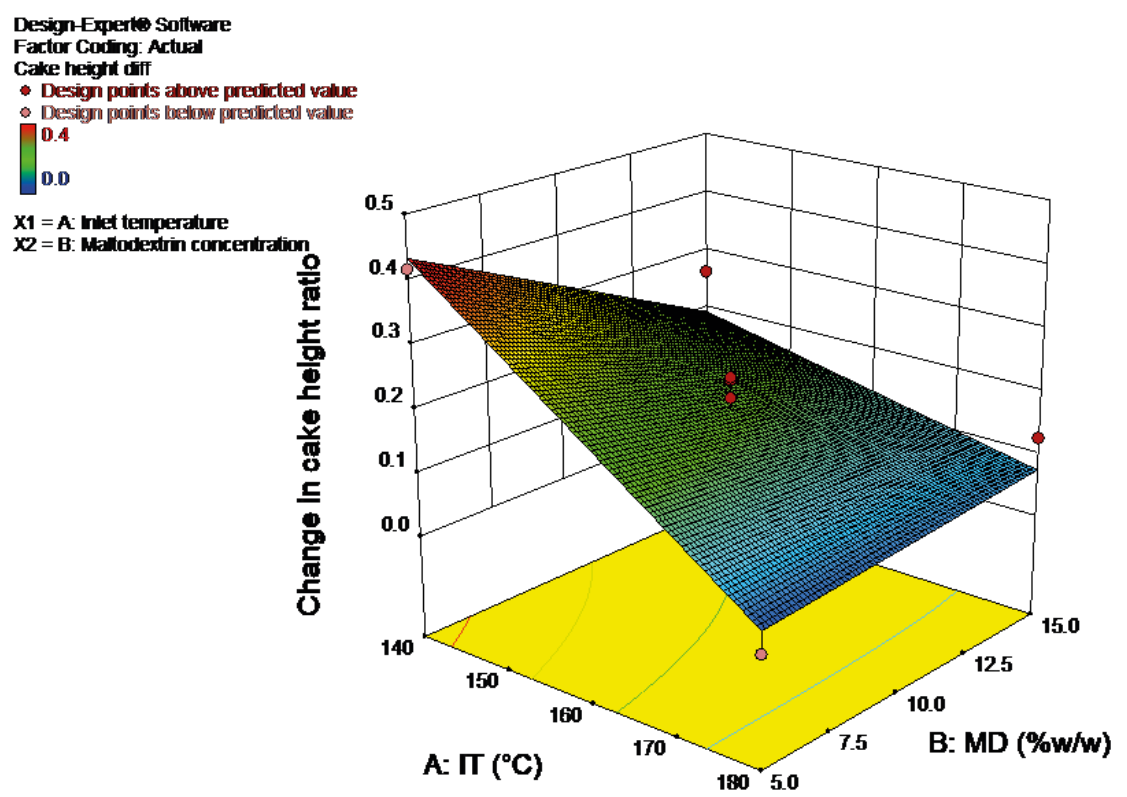

Fig. 2. Response surface plot for effects of inlet air temperature and maltodextrin concentration on the change in cake height ratio $\left(\mathrm{Y}_{9}\right)$ of spray-dried 'cempedak' fruit powder: IT - inlet air temperature, MD - maltodextrin concentration

the 'cempedak' fruit powder obtained in this study had a range of 10.1-12.9, indicating that the powder is in a free-flowing state (Benković and Bauman, 2009).

\section{Influence of independent variables on the particle size of spray-dried 'cempedak' fruit powder}

A particle size larger than $200 \mu \mathrm{m}$ is defined as free flowing, while finer powders are prone to being cohesive and reduced in flowability (Benković and Bauman, 2009). From Table 2, the particle size $\left(\mathrm{Y}_{8}\right)$ of the 'cempedak' fruit powder ranged from 118.1-268.72 $\mu \mathrm{m}$. However, the inlet air temperature and maltodextrin concentration had no significant effect on the particle size of the powder. This is in agreement with the work of Bednarska et al. (2020) on the spray-drying of chokeberry juice powder.

\section{Influence of independent variables on the surface morphology of spray-dried 'cempedak' fruit powder}

Morphological images of 'cempedak' fruit powder produced at different inlet air temperatures and maltodextrin concentrations, captured using a scanning electron microscope, are shown in Figure 4. It can be observed that the 'cempedak' juice spray-dried at inlet air temperatures that are lower $\left(132-160^{\circ} \mathrm{C}\right)$ had smoother surfaces compared to the wrinkled and shriveled surfaces that can be observed on the surface of 'cempedak' fruit powder spray-dried at $188^{\circ} \mathrm{C}$. Higher shrinkage at higher spray-drying temperatures may be due to the transportation of moisture during the falling rate period (Walton, 2000).

The increase in maltodextrin concentration produces powder with a smoother surface. With the addition of less maltodextrin $(2.9 \% \mathrm{w} / \mathrm{w})$, the powder had a shriveled surface. On the other hand, more maltodextrin $(17 \% \mathrm{w} / \mathrm{w})$ incorporated into the spraydrying feed produced powder with a smooth surface and round particles. Bednarska et al. (2020) observed that most of the spray-dried chokeberry powder had a creased and spherical shape. Ferrari et al. (2012) also found that maltodextrin addition leads to the production of blackberry powder with a smoother surface. Maltodextrin contains sugars with a low molecular weight, which function as plasticizers and prevent the 
(a) Different inlet temperatures

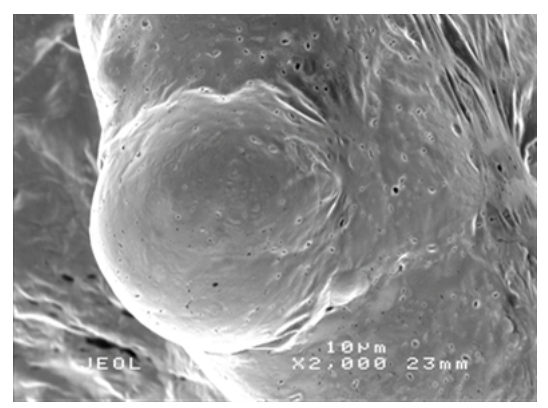

$132^{\circ} \mathrm{C}, 10 \%(\mathrm{w} / \mathrm{w})$ maltodextrin

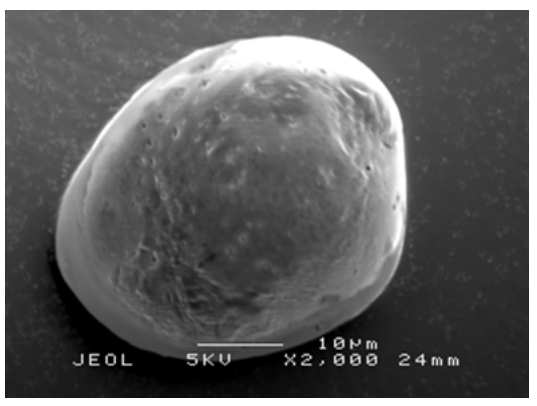

$160^{\circ} \mathrm{C}, 10 \%(\mathrm{w} / \mathrm{w})$ maltodextrin

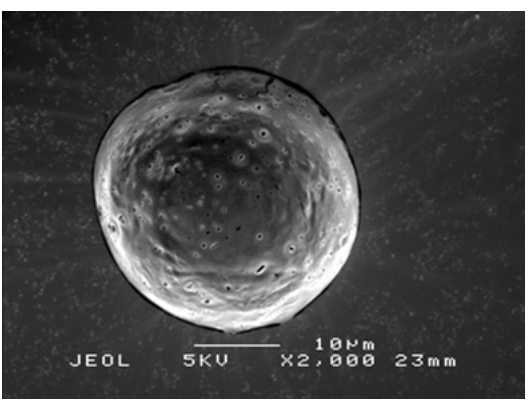

$188^{\circ} \mathrm{C}, 10 \%(\mathrm{w} / \mathrm{w})$ maltodextrin

(b) Different maltodextrin concentrations

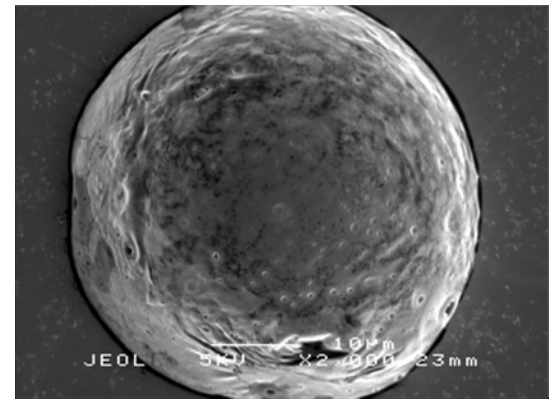

$2.9 \%(\mathrm{w} / \mathrm{w})$ maltodextrin, $160^{\circ} \mathrm{C}$

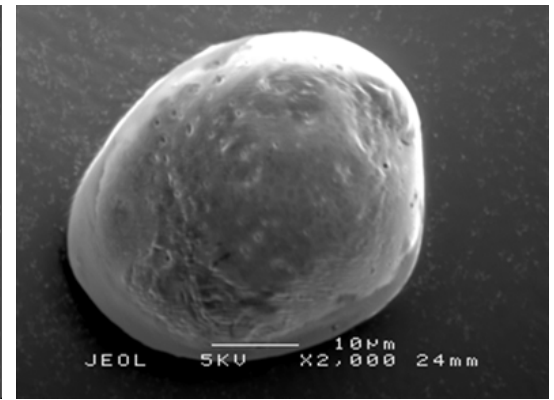

$10 \%(\mathrm{w} / \mathrm{w})$ maltodextrin, $160^{\circ} \mathrm{C}$

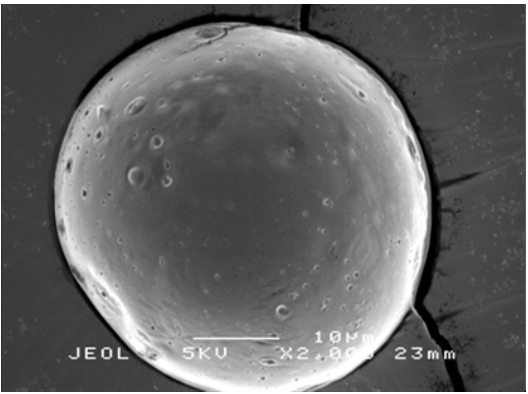

$17 \%(\mathrm{w} / \mathrm{w})$ maltodextrin

Fig. 3. Morphological images of 'cempedak' fruit powder produced at different inlet air temperatures (a) and with different maltodextrin concentrations (b) (2000× magnification)

shrinkage of the powder surface. This leads to the formation of smooth particles (Loksuwan, 2007).

\section{Influence of independent variables on water solubility index of reconstituted spray-dried 'cempedak' fruit powder}

Food powders with good solubility are a must for them to be applied to a product or consumed (Caliskan and Dirim, 2013; Chen and Patel, 2008). In Table 2, the water solubility index of the 'cempedak' fruit powder $\left(\mathrm{Y}_{15}\right)$ ranges from 74.02-90.21. The independent variables (inlet air temperature) and their interactions (linear, quadratic and interaction) show a significant effect $(p \leq 0.05)$ on the water solubility index of 'cempedak' fruit powders (Table 2), with inlet air temperature having a higher $F$-ratio value (Table 4 ), indicating that the drying temperature is more dominant in its effect on powder solubility.
The linear effect of inlet air temperature had the highest positive correlative effect on the water solubility index of spray-dried 'cempedak' fruit powder (Table 3 and Fig. 4). The powder produced at a low inlet air temperature had a higher moisture content and a higher tendency towards agglomeration, helping to increase the reconstitution of the powders (Quek et al., 2007). Higher spray-drying temperatures tend to reduce powder moisture content, making the powder more soluble (Bakar et al., 2013). The water solubility index was also positively affected by maltodextrin concentration (Table 3 ). The addition of maltodextrins improved the solubility of powder as maltodextrin has good water solubility (Pinthong et al., 2019). In addition, higher maltodextrin may also be due to the less insoluble and smaller lumps in the powder, which increase the powder's water solubility index (Abadio et al., 2004; Jaya and Das, 2005). 


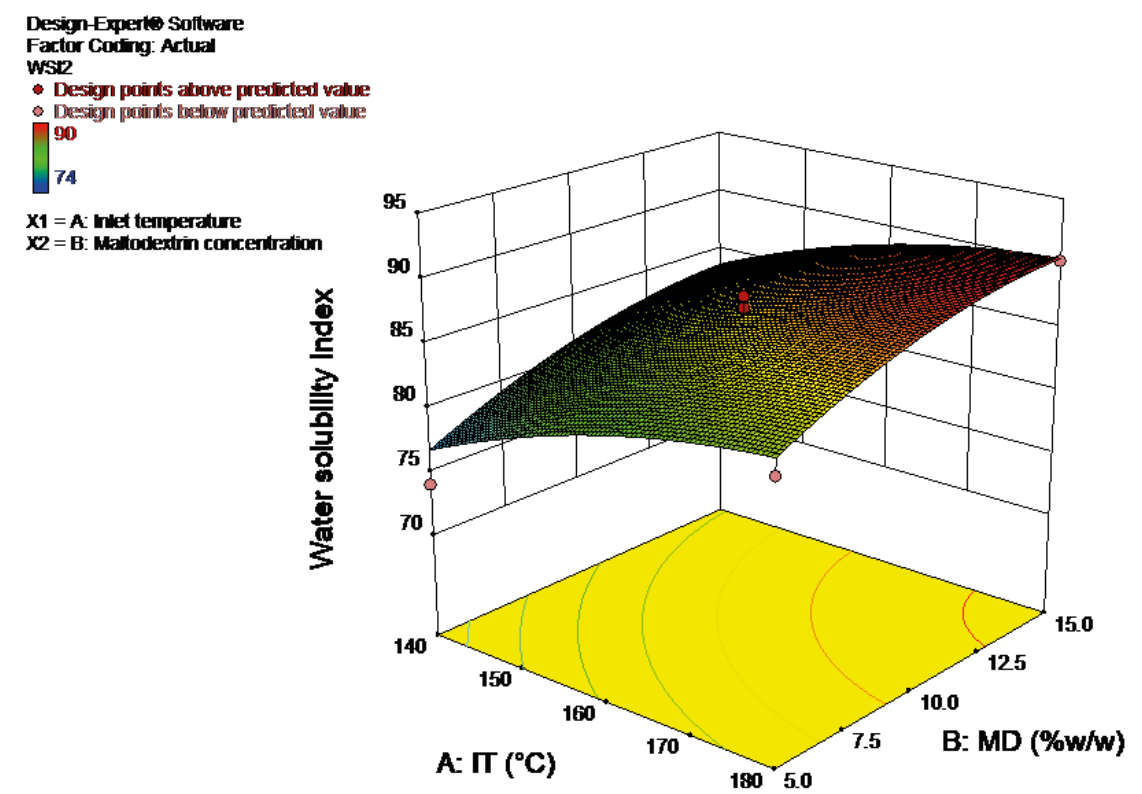

Fig. 4. Response surface plot for effects of inlet air temperature and maltodextrin concentration on the water solubility index $\left(\mathrm{Y}_{15}\right)$ of spray-dried 'cempedak' fruit powder: IT - inlet air temperature, MD - maltodextrin concentration

\section{Influence of independent variables on the color and viscosity of reconstituted spray-dried 'cempedak' fruit powder}

Both inlet air temperature and maltodextrin concentration (Table 2) had no significant effect $(p>0.05)$ on the color change between juice (spray-dryer feed) and reconstituted powder $\left(\mathrm{Y}_{20}\right)$, and the viscosity of reconstituted spray-dried 'cempedak' fruit powder $\left(\mathrm{Y}_{21}\right)$. The carotenoids, as the main group of pigments responsible for the red and yellow color of the product, were encapsulated (Kha et al., 2010). The total color change obtained in this study was too small to be detected visually, except for in the powder spray-dried at $180^{\circ} \mathrm{C}$ (Obón et al., 2009). Martínez-Navarrete et al. (2018) reported that grapefruit juice reconstituted from spray-dried powder has color changes due to heat during the spray-drying process.

\section{Optimization of independent variables and verification of the final models}

In relation to the powder flow and solubility properties of the powder, the goal was to set (minimum or maximum) the properties of the developed product (spraydried 'cempedak' fruit powder), as shown in Table 5.

Table 5. Criteria and outputs of the numerical optimization of the responses for 'cempedak' fruit powder processing

\begin{tabular}{lcccc}
\hline \multicolumn{1}{c}{ Responses } & Goal & Lower limit & Upper limit & Importance \\
\hline Inlet air temperature, ${ }^{\circ} \mathrm{C}$ & is in range & 140 & 180 & 3 \\
Maltodextrin concentration, $\% \mathrm{w} / \mathrm{w}$ & is in range & 5 & 15 & 3 \\
Bulk density $\left(\mathrm{Y}_{1}\right), \mathrm{kg} / \mathrm{m}^{3}$ & minimize & 387.1 & 530.2 & 2 \\
Change in cake height ratio $\left(\mathrm{Y}_{5}\right)$ & minimize & 0.005 & 0.417 & 5 \\
Water solubility index $\left(\mathrm{Y}_{9}\right)$ & maximize & 74.02 & 90.21 & 5 \\
\hline
\end{tabular}




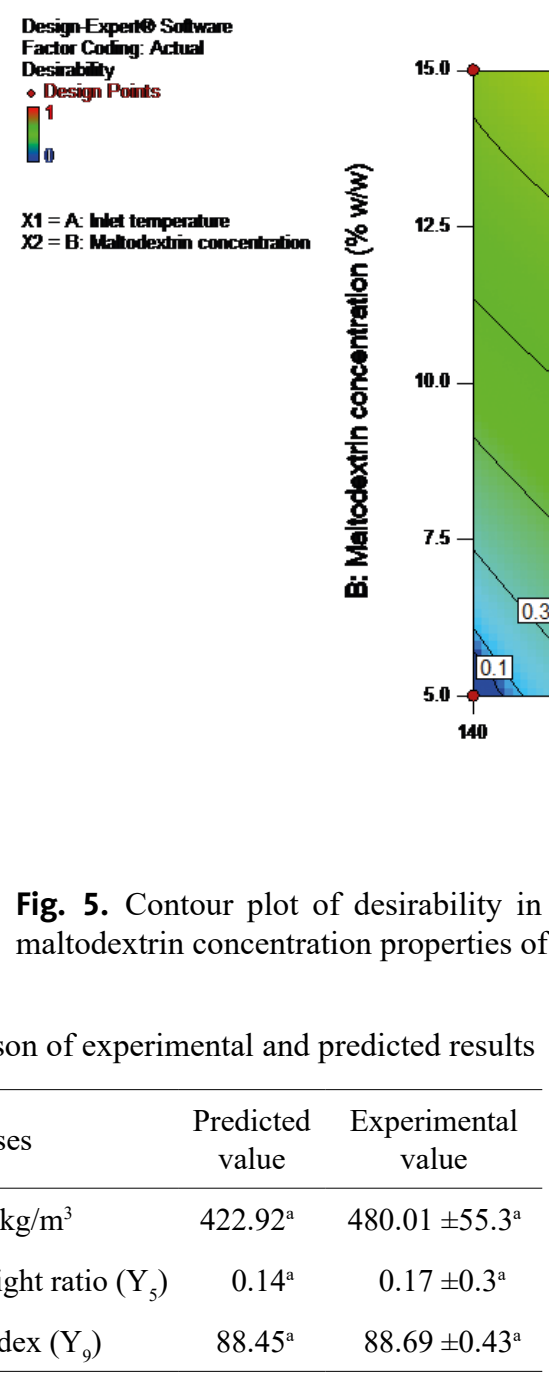

Spray-drying of 'cempedak' juice was conducted at $160^{\circ} \mathrm{C}$ with the addition of $15 \%$ maltodextrin, $\mathrm{w} / \mathrm{w}$.

Each value represents the mean of triplicate samples \pm standard deviation.

Values within the same row with different superscript $(a-b)$ are significantly different at $p \leq 0.05$, as measured by Tukey's HSD test.

The results indicate that 'cempedak' juice spray-dried at $160^{\circ} \mathrm{C}$ with the addition of maltodextrin $(1.5 \%$ $\mathrm{w} / \mathrm{w}$ ) is the optimum parameter (Fig. 5), where the experimental values were found to be close to those predicted, in which there was no significant difference found $(p>0.05)$ in the aspects of bulk density, caking (change in cake height ratio) and water solubility index. Table 6 shows that most of the predicted responses were close to the experimental values.

\section{CONCLUSION}

Response surface methodology (RSM) using central composite design (CCD) were used to study the effects of inlet air temperature $\left(140-180^{\circ} \mathrm{C}\right)$ and maltodextrin (DE 10) concentrations $(5-15 \% \mathrm{w} / \mathrm{w})$ on the powder flow and reconstitution properties of spray-dried 'cempedak' fruit powder. All the response variables bulk density, caking (change in cake height ratio), and water solubility index $\left(R^{2}>0.80\right)$ - were significantly matched to the response surface models, with predicted values that are similar to the experimental values. Response variables were most influenced by the linear term of inlet air temperature, followed by a linear term of maltodextrin concentration. The optimum parameters for the production of spray-dried 'cempedak' were an inlet air temperature of $160^{\circ} \mathrm{C}$ and maltodextrin DE10 at a concentration of $15 \%(\mathrm{w} / \mathrm{w})$.

\section{REFERENCES}

Abadio, F. D. B., Domingues, A. M., Borges, S. V., Oliveira, V. M. (2004). Physical properties of powdered pineapple (Ananas comosus) juice-effect of maltodextrin 
Pui, L. P., Karim, R., Yusof, Y. A., Wong, Ch. W., Ghazali, H. M. (2021). Effects of inlet temperature and carrier concentration on spray-dried 'cempedak' (Artocarpus integer) fruit powder and its reconstitution properties. Acta Sci. Pol. Technol. Aliment., 20(2), 135-148. http://dx.doi.org/10.17306/J.AFS.2021.0801

concentration and atomization speed. J. Food Eng., 64, 285-287.

Aguilera, J. M., del Valle, J. M., Karel, M. (1995). Caking phenomena in amorphous food powders. Trends Food Sci. Technol., 6(5), 149-155. https://doi.org/10.1016/ S0924-2244(00)89023-8

Bakar, J., Ee, S. C., Muhammad, K., Hashim, D. M., Adzahan, N. (2013). Spray-drying optimization for red pitaya peel (Hylocereus polyrhizus). Food Bioproc. Tech., 6, 1332-1342. https://doi.org/10.1007/s11947-012-0842-5

Bednarska, M. A., Janiszewska-Turak, E. (2020). The influence of spray drying parameters and carrier material on the physico-chemical properties and quality of chokeberry juice powder. Int. J. Food Sci., 57(2), 564-577. https://doi.org/10.1007/s13197-019-04088-8

Benković, M., Bauman, I. (2009). Flow properties of commercial infant formula powders. Int. J. Bio. Biomol. Agric. Food Biotechnol. Eng., 3(6), 304-308.

Benković, M., Srečec, S., Špoljarić, I., Mršić, G., Bauman, I. (2013). Flow properties of commonly used food powders and their mixtures. Food Bioproc. Tech., 6, 25252537. https://doi.org/10.1007/s11947-012-0925-3

Bhandari, B.R., Dutta, N., Howes, T. (1997). Problems associated with spray drying of sugar-rich food. Dry. Technol., 15, 671-684. https://doi. org/10.1080/07373939708917253

Bhusari, S. N., Muzaffar, K., Kumar, P. (2014). Effect of carrier agents on physical and microstructural properties of spray dried tamarind pulp powder. Powder Technol., 266, 354-364. https://doi.org/10.1016/j.powtec.2014.06.038

Caliskan, G., Dirim, S.N. (2013). The effects of the different drying conditions and the amounts of maltodextrin addition during spray drying of sumac extract. Food Bioprod. Process., 91, 539-548. https://doi.org/10.1016/j. fbp.2013.06.004

Caliskan, G., Nur Dirim, S. (2016). The effect of different drying processes and the amounts of maltodextrin addition on the powder properties of sumac extract powders. Powder Technol., 287, 308-314. https://doi. org/10.1016/j.powtec.2015.10.019

Chang, L. S., Tan, Y. L., Pui, L. P. (2020a). Production of spray-dried enzyme-liquefied papaya (Carica papaya L.) powder. Braz. J. Food Technol., 23, e2019181 [in press]. https://doi.org/10.1590/1981-6723.18119

Chang, L. S., Yong, S. M. E., Pui, L. P. (2020b). Production of spray-dried "Terung Asam" (Solanum lasiocarpum Dunal) powder. Walailak J. Sci. Tech. [in press].

Chen, X. D., Patel, K. C. (2008). Manufacturing better quality food powders from spray drying and subsequent treatments. Dry Technol., 26 (11), 1313-1318. https:// doi.org/10.1080/07373930802330904

Chew, S., Tan, C., Pui, L., Chong, P., Gunasekaran, B., Nyam, K. (2019). Encapsulation technologies: A tool for functional foods development. ITIJEE, 8(5S).

de Oliveira, M. A., de Maia, G. A., de Figueirado, R. W., de Souza, A. C. R., de Brito, E. S., de Azeredo, H. M. (2009). Addition of cashew tree gum to maltodextrinbased carriers for spray drying of cashew apple juice. Int. J. Food Sci. Tech., 44, 641-645. https://doi.org/10.1111/ j.1365-2621.2008.01888.x

Doymaz, I., Kocayigit, F. (2011). Drying and rehydration behaviours of convection drying of green peas. Dry Technol., 29 (11), 1273-1282. https://doi.org/10.1080/0 7373937.2011 .591713

Fang, Y., Selomulya, C., Chen, X. D. (2007). On measurement of food powder reconstitution properties. Dry Technol., 26(1), 3-14. https://doi.org/10.1080/0737393 0701780928

Ferrari, C. C., Germer, S. P. M., de Aguirre, J. M. (2012). Effects of spray-drying conditions on the physicochemical properties of blackberry powder. Dry Technol., 30, 154 163. https://doi.org/10.1080/07373937.2011.628429

Freeman, R. (2007). Measuring the flow properties of consolidated, conditioned and aerated powders - a comparative study using a powder rheometer and a rotational shear cell. Powder Technol., 174(1-2), 25-33. https:// doi.org/10.1016/j.powtec.2006.10.016

Goula, A. M., Adamopoulos, K. G. (2008). Effect of maltodextrin addition during spray drying of tomato pulp in dehumidified air: I. Drying kinetics and product recovery. Dry Technol., 26, 714-725. https:/doi. org/10.1080/07373930802046369

Grabowski, J. A., Truong, V. D., Daubert, C. R. (2006). Spray-drying of amylase hydrolyzed sweet potato puree and physicochemical properties of powder. J. Food Sci., 71, 209-217. https://doi.org/10.1111/j.17503841.2006.00036.x

Grabowski, J. A., Truong, V. D., Daubert, C. R. (2008). Nutritional and rheological characterization of spray dried sweet potato powder. LWT - Food Sci. Technol., 41, 206-216. https://doi.org/10.1016/j.lwt.2007.02.019

Grandison, A. S., Lewis, M. J. (Eds., 1996). Separation processes in the food and biotechnology industries: Principles and applications. Woodhead Publishing.

Janick, J., Paull, R. E. (Eds., 2008). The encyclopedia of fruit and nuts. CABI.

Janjatović, D., Benković, M., Srečec, S., Ježek, D., Špoljarić, I., Bauman, I. (2012). Assessment of powder flow characteristics in incoherent soup concentrates. 
Pui, L. P., Karim, R., Yusof, Y. A., Wong, Ch. W., Ghazali, H. M. (2021). Effects of inlet temperature and carrier concentration on spray-dried 'cempedak' (Artocarpus integer) fruit powder and its reconstitution properties. Acta Sci. Pol. Technol. Aliment., 20(2), 135-148. http://dx.doi.org/10.17306/J.AFS.2021.0801

Adv. Powder Technol., 23, 620-631. https://doi. org/10.1016/j.apt.2011.07.003

Jaya, S., Das, H. (2005). Accelerated storage, shelf life and color of mango powder. J. Food Process. Preserv., 29, 4562. https://doi.org/10.1111/j.1745-4549.2005.00012.x

Kha, T. C., Nguyen, M. H., Roach, P. D. (2010). Effects of spray drying conditions on the physicochemical and antioxidant properties of the Gac (Momordica cochinchinensis) fruit aril powder. J. Food Eng., 98, 385-392. https://doi.org/10.1016/j.jfoodeng.2010.01.016

Lim, L. B. L., Chieng, H. I., Wimmer, F. L. (2011). Nutrient composition of Artocarpus champeden and its hybrid (Nanchem) in Negara Brunei Darussalam. Asean J. Sci. Technol. Developm., 25(2), 122-138. https://doi. org/10.29037/ajstd.39

Loksuwan, J. (2007). Characteristics of microencapsulated b-carotene formed by spray drying with modified tapioca starch, native tapioca starch and maltodextrin. Food Hydrocoll., 21, 928-935. https://doi.org/10.1515/15563758.2647

Martínez-Navarrete, N., Camacho, M. M., Agudelo, C., Salvador, A. (2019). Sensory characterization of juice obtained via rehydration of freeze-dried and spray-dried grapefruit. J. Sci. Food Agric., 99(1), 244-252. https:// doi.org/10.1002/jsfa.9166

Ng, L. T., Chong, P. H., Yusof, Y. A., Chin, N. L., Talib, R. A., Tapi, F. S., Aziz, M. G. (2012). Physicochemical and nutritional properties of spray-dried pitaya fruit powder as natural colorant. Food Sci. Biotechnol., 21(3), 675682. https://doi.org/10.1007/s10068-012-0088-z

Obón, J. M., Castellar, M. R., Alacid, M., Fernandez-Lopez, J. A. (2009). Production of a red-purple food colorant from Opuntia stricta fruits by spray drying and its application in food model systems. J. Food Eng., 90, 471479. https://doi.org/10.1016/j.jfoodeng.2008.07.013

Phisut, N. (2012). Spray drying technique of fruit juice powder: some factors influencing the properties of product. Int. Food Res. J., 19, 1297-1306.

Pinthong, S., Judprasong, K., Tangsuphoom, N., Jittinandana, S., Nakngamanong, Y. (2019). Effect of different drying processes on physical properties and carotenoid content of Gac fruit (Momordica cochinchinensis Spreng.). JFAT, 5, 61-70.

Pua, C. K., Hamid, S. A., Tan, C. P., Mirhosseini, H., Rahman, R. A., Rusul, G. (2008). Storage stability of jackfruit (Artocarpus heterophyllus) powder packaged in aluminum laminated polyethylene and metallized coextruded biaxially oriented polypropylene during storage. J. Food Eng., 89, 41-428. https://doi.org/10.1016/j. jfoodeng.2008.05.023

Pui, L. P., Karim, R., Yusof, Y. A., Wong, C. W., Ghazali, H. M. (2018). Physicochemical and sensory properties of selected 'cempedak' (Artocarpus integer L.) fruit varieties. Int. Food Res. J., 25(2), 861-869.

Quek, S. Y., Chok, N. K., Swedlund, P. (2007). The physicochemical properties of spray dried watermelon powders. Chem. Eng. Process., 46, 386-392. https://doi. org/10.1016/j.cep.2006.06.020

Shah, R. B., Tawakkul, M. A., Khan, M. A. (2008). Comparative evaluation of flow for pharmaceutical powders and granules. AAPS PharmSciTech., 9 (1), 250-258. https:// doi.org/10.1208/s12249-008-9046-8

Shavakhi, F., Boo, H. C., Osman, A., Ghazali, H. M. (2012). Effects of enzymatic liquefaction, maltodextrin concentration, and spray-dryer air inlet temperature on pumpkin powder characteristics. Food Bioproc. Tech., 5 (7), 2837-2847. https://doi.org/10.1007/s11947-011-0686-4

Solval, K. M., Sundarajan, S., Alfaro, L., Sathivel, S. (2012). Development of cantaloupe (Cucumis melo) juice powders using spray-drying. LWT - Food Sci. Technol., 46, 287-293. https://doi.org/10.1016/j.lwt.2011.09.017

Subhadrabandhu, S. (2001). Under-utilized tropical fruits of Thailand. Bangkok: Regional Office Asia and the Pacific FAO.

Tonon, R. V., Brabet, C., Hubinger, M. D. (2008). Influence of process conditions on the physicochemical properties of acai (Euterpe oleraceae Mart.) powder produced by spray drying. J. Food Eng., 88, 411-418. https://doi. org/10.1016/j.jfoodeng.2008.02.029

Walton, D. E. (2000). The morphology of spray-dried particles a qualitative view. Dry. Technol., 18(9), 1943-1986.

Wong, C. W., Pui, L. P., Ng, J. M. L. (2015). Production of spray-dried Sarawak pineapple (Ananas comosus) powder from enzyme liquefied puree. Int. Food Res. J., 22(4), 1631-1636.

Yousefi, S., Emam-Djomeh, Z., Mousavi, S. M. (2011). Effect of carrier type and spray drying on the physicochemical properties of powdered and reconstituted pomegranate juice (Punica Granatum L.). Int. J. Food Sci. Tech., 48(6), 677-684. https://doi.org/10.1007/ s13197-010-0195-x 